Laboratory Introduction to

Bio-inorganic Chemistry 


\title{
Laboratory Introduction to Bio-inorganic Chemistry
}

\author{
Ei-Ichiro Ochiai, BSc, PhD \\ Department of Chemistry \\ University of British Columbia \\ and
}

David R. Williams, BSc, PhD, CChem, FRIC, DSc

Department of Chemistry

University of Wales Institute of Science and Technology

Cardiff 
(c) Ei-Ichiro Ochiai and David R. Williams 1979

All rights reserved. No part of this publication may be reproduced or transmitted, in any form or by any means, without permission

First published 1979 by

THE MACMILLAN PRESS LTD

London and Basingstoke

Associated companies in Delhi Dublin

Hong Kong Johannesburg Lagos Melbourne

New York Singapore and Tokyo

Typeset by

Reproduction Drawings Ltd, Sutton, Surrey

\section{British Library Cataloguing in Publication Data}

Ochiai, Ei-Ichiro

Laboratory introduction to bio-inorganic

chemistry.

1. Biological chemistry-Laboratory manuals

2. Chemistry, inorganic-Laboratory manuals

I. Title II. Williams, David Raymond

574.1'921'028

QP531

ISBN 978-0-333-23681-9

ISBN 978-1-349-86127-9 (eBook)

DOI 10.1007/978-1-349-86127-9

This book is sold subject to the standard conditions of the Net Book Agreement

The paperback edition of this book is sold subject to the condition that it shall not, by way of trade or otherwise, be lent, resold, hired out, or otherwise circulated without the publisher's prior consent in any form of binding or cover other than that in which it is published and without a similar condition including this condition being imposed on the subsequent purchaser 


\section{Contents}

Preface

Part A

Analysis of Trace Elements in Biological Materials

Chapter I Introduction: Bio-inorganic Chemistry as a Laboratory Discipline

$\begin{array}{lll}\text { Chapter II Treatment of Biological Material } & 7\end{array}$

Chapter III Laboratory Experiments 9

1 Determination of Chloride in Biological Fluids by Thermometric Titrimetry

2 A Copper(II) Ion Sensitive Electrode for Copper Assay 14

3 Atomic Absorption Analysis of Manganese and Zinc in Leaves 17

4 The Determination of Calcium and Magnesium in Fruit Juice 20

5 Trace Elements in Sea Water $\quad 21$

6 Trace Elements in Hair and Blood 23

7 Estimation of Lithium in Drinking Water 25

8 Estimation of Water Contamination $\quad 26$

9 Air Pollution Studies $\quad 29$ 


\section{Part B}

Inorganic Chemistry Relevant to Biological Sciences

Chapter IV The Basic Principles of Coordination Chemistry 35

Chapter V Instrumental Measurements 43

Chapter VI Laboratory Experiments 46

10 The Preparation, Characterisation and Screening of Pharmaceutically Active Metal Complexes 46

11 Nickel(II)-Glycine Interactions Studied by pH Potentiometry 49

12 Determination of Formation Constants of Calcium-ATP Complexes 56

13 The Passage of Metal Ions through Cell Membranes 62

14 Stereochemistry of $\mathrm{Co}(\mathrm{III})\left(\right.$ trien) $\mathrm{X}_{2}$, and Reaction of Coordinated Glycine Esters

15 Effects of Axial Ligands on Tetragonal Metal Complexes related to Haemoglobin, etc.

16 Interaction of Pyrophosphate with Metal Ions 74

17 Metal Ion-Protein Interactions

\section{Part C}

Enzymes, Proteins and Model Studies

Chapter VIII Laboratory Experiments $\quad 85$

18 Haemoglobin-Oxygenation, and Magnetic and Spectroscopic Studies 85

19 Oxygenation of Co(salen)-A Model for Haemoglobin 93

20 EPR Study of Co(salen), $\mathrm{Co}\left(\right.$ salen) $-\mathrm{O}_{2}$ Systems 97

21 Vitamin $\mathrm{B}_{12}$ and Model Compounds 104

22 Catalase and Model Compounds 115

23 Hexokinase-Effects of Metal Ions 119

24 The Effects of Metal Ions on Polynucleotides (DNA) 121

25 Computer Simulations of Complexing Systems in vivo 124 


\section{Preface}

Within the last 20 years there have been many advances in our understanding of the role of elements in vivo. Such achievements arise from painstaking researches in many disciplines-biochemistry, inorganic reaction mechanisms, medicine, pharmacology-to mention but a few. The need to supply a steady stream of researchers has been reflected in a demand for bio-inorganic courses at undergraduate level. This trend has been supplemented with a wide range of service courses for medical students and applied biologists. Several textbooks have been published and there is a clear need to reinforce lecture and textbook instruction with laboratory training and experience. This book is a laboratory manual which collects experiments that may be used to drive home the principles of bioinorganic chemistry.

Readers who expect to find experiments in which, for example, metal salts are administered to an animal and then some sophisticated scheme of reaction mechanism is derived, will be disappointed! Many of these experiments are fundamental to inorganic chemistry or pharmacology but they have now been adapted to consider either biological material or the presence of metals. The relationships between such experiments and bio-inorganic principles are indicated in the Introductions but it must be emphasised that the activation energy necessary to turn these experiments into direct educational relevance for each specific lecture course being mounted must, and can only, come from the course instructors.

Since the human body contains about $10^{6}$ different solutions (i.e. solutions entrapped inside living cells) we have arbitrarily classified experiments into analysis of components of a cell, the inorganic chemistry occurring in vivo and the metaloenzyme-metalloprotein chemistry occurring in the micro environments of enzyme 
active sites within cells. There could have been many other types of classification since bio-inorganic chemistry is contingent upon so many branches of natural science.

We have procured experiments from many sources and obtained our own experiences before writing them herein. However, we should like to express our thanks particularly to Professor A. G. Splittgerber of Gustavus Adolphus College who is the original developer of Exp.18(a) and (b), Professor W. H. Sawyer of the University of Melbourne (for Exp.18(c)), Dr. Y. Koga of the University of British Columbia (for Exp.6(a)), Dr. J. T. Roos of Marlborough College (for Exp.3-7), Mr. P. M. May of UWIST 9 for Exp.11 and 25), Dr. D. E. Fenton of Sheffield University (Exp.18) and Ms K. Oliver (Exp.21). We should also like to thank Mr. B. Clifford for technical assistance in developing some of the experiments at the University of British Columbia.

We would value receiving ideas from fellow instructors with a view to an improved second edition.

'We gather a posy of other men's flowers but the thread which connects them is our own.' 